\title{
"GOING FORWARD": A DIACHRONIC ANALYSIS OF THE THESAURUS LINGUAE LATINAE
}

\author{
ANTHONY CORBEILL
}

\begin{abstract}
$\sim$
Abstract. The article anteeo, written by Wilhelm Bannier, was published in the Thesaurus Linguae Latinae (TLL) in 1901. This entry has been rewritten according to contemporary standards at the institute and edited at each step in the process by editors currently at TLL. In comparing the two versions, I discuss differences between anteeo 1901 and 2007 in matters such as methods of data retrieval, rates of composition, levels of accuracy, and editorial policies. The article evaluates both the pros and cons of developments at Munich, while also serving as a primer on how to "read" a TLL article.
\end{abstract}

The Thesaurus LinguaE LATINAE (TLL), the most comprehensive dictionary ever attempted for classical Latin-indeed, for any major language-, has been in preparation for well over a century. Collection of material began in 1894, with a projected date of completion for the entire lexicon of 1915. In 1900 the first printed fascicle appeared, framed by two lemmata that Wilfried Stroh (2005) has characterized as "ominöse" (A-absurdus). As 2007 begins, over two-thirds of the lexicon has seen publication. Work will soon close on volume X, comprising words that begin with the letter "P" (begun in 1976), and the Internationale ThesaurusKommission decided in July 2005 that the staff in Munich will then turn its attention concurrently to lemmata beginning with the letters " $N$ " (previously skipped because of difficult or common words such as nam, natura, and non) and the more manageable "R" (Beikircher 2005, 62). The Kommission had previously chosen to postpone the letter "Q" for reasons clear to anyone with even a minimal amount of Latin.

Tidily ensconced in boxes over these one-hundred-plus years of scholarly industry, the archival resources retain their original form. A set of paper slips, the majority written out by hand and mechanically reproduced in the 1890s, contains every word found in our extant texts from the beginnings of the Latin language up to the Antonine period in the second century C.E. For subsequent years up to approximately 600 C.E., when the Romance languages began to come into their own, 
the archive contains, with a few exceptions, only excerpted material. ${ }^{1}$ These excerpts primarily record either neologisms or words that have undergone significant semantic broadening since the second century. The original slips have been consistently supplemented by addenda, so that they now number over ten million. ${ }^{2}$ Any benefits accrued from putting this amount of data on computer would not, it is argued, justify the massive labor required.

In contrast with this outmoded method of data storage, the scholarly approach promoted at TLL has undergone constant reevaluation since 1900 . The intervening century has not only witnessed greater quality control and an adoption of increasingly sophisticated lexicographic techniques, but it has also fostered a heightened sensitivity to readerfriendliness. In order to outline this development through particular examples, I have rewritten according to contemporary standards, and with assistance from the TLL staff in Munich, the article on anteeo, originally written by Wilhelm Bannier and appearing in 1901, the second year of the lexicon's publication. ${ }^{3}$ I use the word "article" deliberately, since an appreciation of the connotations of this word is in part what I intend to foster through the following exposition. Each entry in the lexicon is a work of scholarship in its own right, involving the selection, organization, and interpretation of the material by an individual scholar whose efforts are then vetted by a trained team of editors. At the same time, and as the author's name given at the end of each entry in the lexicon advertises, a TLL entry necessarily imposes on a once organic word a subjective form of organization within which is fitted (and sometimes repressed) the relevant ancient evidence. My remarks therefore will include a consideration of the tensions between these individually crafted contributions and the apparently monolithic project of which they form a part.

The verb anteire has a basic meaning-"to go ahead of, to surpass"- that describes auspiciously the diachronic development of TLL. In what follows I should like to delineate the principal features of this development and, in so doing, describe the ways in which TLL has worked

${ }^{1}$ Exceptions include Augustine's De civitate Dei, the Vulgate, and Justinian's Digest, all of which were fully excerpted. A full list is given at Praemonenda 1990, 28, n. 1.

${ }^{2}$ For a convenient overview in English of the TLL's history and methodology, see Praemonenda 1990, 25-34. Flury 1995 offers an authoritative account of the various transformations in working methods adopted at TLL over the course of the twentieth century; Bögel 1996 provides a personal memoir of the project's early decades.

${ }^{3}$ I owe the idea for this approach to Peter Flury; Flury 1987, 8-15, compares the two published lemmata antecedo (1900) and praecedo (1983). 
to define itself as the ultimate authority on classical Latin usage while at the same time balancing this status with its assertion that the Thesaurus article "cannot and is not intended to be definitive" (Praemonenda 1990, 31). I shall conclude by giving examples of how this progress is countered by an increase in the difficulty that the lexicon presents for users who approach it for the first time. The TLL's language, like any language, must be learned, and the development of its own lexicographic shorthand can tend to render the text intimidating and bewildering to the uninitiated. Three principal criteria govern the choice of anteeo for this exercise: (1) a verb provides a more comprehensive demonstration of the developing lexicographical principles in Munich than would another part of speech; (2) the number of extant occurrences of the lemma is large enough to demonstrate this development, but small enough for a reader to understand readily the verb's range of meanings; (3) anteeo allows comparison with the recently published article on the verb's approximate synonym, praeeo.

The article in appendix C labeled "Anteeo 2007 as Rewritten" was composed in accordance with contemporary practice in Munich. Like Bannier a century earlier, I began work with a review of all the slips (Zettel) for the lemma that are stored in the Thesaurus archive. For Bannier, the slips normally constituted the sole source of information. In 2007, however, with the assistance of the second edition of the Index (1990), an author is also expected to consult the most recent authoritative editions and commentaries for each passage found in the material. Since these editions and commentaries normally exploit TLL in interpreting the original Latin text, there is a slight risk of circularity involved in the procedure when, say, the context surrounding the lemma under consideration has been reconstructed with the assistance of earlier volumes of the lexicon. ${ }^{4}$ And yet such a risk is balanced by the contributions that these same editors and commentators can offer, since they frequently take the opportunity to supplement, nuance, and correct TLL items already published.

After determining a range of meanings from the archival slips, the first step in writing involved constructing a skeletal framework (Disposition) of the projected article that grouped the material according to semantic and syntactical criteria. This framework was extensively critiqued and revised by my editor, Cornelis van Leijenhorst, in consultation with the Thesaurus's then Generalredaktor Peter Flury, to produce the Disposition displayed in appendix A (anteeo 2007). With this framework in place, 
I began the process of selecting for each section those passages in the archive that best displayed the range of usage found in the extant material. Concurrently, I began to gather information for the opening paragraph (Kopf) of the article (appendix C, lines 1-18; discussed below). The first full draft was again submitted to van Leijenhorst, whose comments called for extensive cutting and revision. ${ }^{5}$ Dr. Flury then further edited the version that had been revised by van Leijenhorst, which included checking independently every ancient quotation that is projected to appear in print. Appendix C contains the final result. Only one significant step was omitted from the normal process of composition for articles published in the lexicon. Prior to submitting electronic versions to the publisher, completed articles are sent to specialists outside the TLL (Fahnenleser), who offer suggestions and make queries from the perspective of an educated user of the lexicon. By this stage, then, in addition to the author a minimum of three professional Latinists will have reviewed and assessed the article. Finally, after formal page proofs arrive at the institute, the original author, the editors responsible for the volume involved, and at least one other lexicographer from the team make a final check for accuracy, primarily in the conversion of the electronic files.

Such an elaborate system of checks and balances did not yet exist when Bannier sat down to compose the original version of anteeo. Most significantly, the authors of individual articles seem not to have had much regular contact with the TLL's sole editor at the time. ${ }^{6}$ A clear indication of this independence can be found in a public lecture given in October 1903 by Friedrich Vollmer, first Generalredaktor of the TLL. Vollmer criticizes the practice of some of his Mitarbeiter for producing articles that contain an excessively elaborate system of division and subdivision, with the separate portions often either unlabeled or marked with imprecise designations such as nota (e.g., abdo [O. Hey]). ${ }^{7}$ Vollmer's criticism is indeed justified: a reader confronted with an article of this sort must spend a great deal of time trying to guess the ordering principle implied by the author. The lack of frequent communication between staff and editor that is indicated by Vollmer's comment becomes further clear from

${ }^{5}$ Current policy at TLL prescribes that entries not surpass five times the size of the corresponding entry in Forcellini 1858-75, a limit that can be exceeded if the amount of material in the archives warrants it (100 slips $=1$ column of published text, 1 box of slips $=10$ columns; note, however, that these numbers do not increase proportionally, i.e., 10 boxes $\neq 100$ columns).

${ }^{6}$ For more on the work of early editors, see Flury 1995, 41-42, 55-56.

${ }^{7}$ Flury 1995,30 , from whose analysis of articles in the early volumes I draw much. 
the account of the day-to-day workings at the institute given by Theodor Bögel, a Mitarbeiter contemporary with Bannier, as well as from the readily observable variety displayed by articles that appear alongside each other in the early volumes. One species of article demonstrates Vollmer's apparently preferred method, which consists principally of few and simple divisions into which the archival matter is dispersed in chronological order. A particular example of this type is Vollmer's own article for the lemma aequor ("level plain"), where semantic differentiation moves little beyond the distinction between planities (a plain on land) and mare (the open sea). ${ }^{8}$ Such articles, which provide only minimal assistance to a modern scholar equipped with digital databases, stand beside a second type that anticipates the various sorts of distinctions and sub-groupings that will be presented more systematically in later volumes (e.g., alo [A. Mess]). The fact that workers could supplement their substandard pay-the equivalent of two-thirds the salary of a Hilfslehrer in a Prussian gymnasium-by receiving eight to ten Marks per published page offers additional grounds for suspecting why some articles betray more haste than others. ${ }^{9}$

The systematic series of checks at the contemporary TLL has had, however, a predictably negative effect on rates of production. During the TLL's first four years of publication, Bannier wrote an annual average of sixty columns of text. ${ }^{10}$ This figure is higher than the average number of columns annually edited by each of the current volume editors (Bandredaktoren). Put in other terms, Bannier's average annual output matches one-quarter of that expected from the approximately twenty staff members working at TLL today. It should further be noted that during this same period Bannier's activity was not limited to the composition of articles for the lexicon. He also acted as assistant administrator to the TLL's secretary, Oskar Hey, and he helped edit the first edition of the Thesaurus Index (1904). ${ }^{11}$

Another factor affecting rates of production is the ever-increasing availability of two related scholarly tools: first, computerized databases, in particular the CDs of Latin texts issued by the Packard Humanities

${ }^{8}$ Additional examples at Flury 1995, 31, n. 4.

${ }^{9}$ On wages, see Bögel 1996, 55-57, with notes of Krömer and Flieger 1996 (“"zu gering ..., wenigstens für diejenigen, die nicht bei ihren Eltern wohnen, und alle diejenigen, die gehofft hatten, ohne Zuschuß von seiten ihrer Eltern auszukommen" [Bögel 1996, 55]); on the allegation of lengthening articles to obtain a higher honorarium, see Bögel 1996, 60, with Krömer and Flieger 1996, 60, n. 1.

${ }^{10}$ Bannier was hired at TLL in 1898 , before collection of the archival material had begun, and remained in various capacities for thirty-six years (Hey 1996, 172).

${ }^{11}$ Administrator: Bögel 1996, 136, with Krömer and Flieger 1996, 136, n. 4. Work on Index: Index 1904, i; Bögel 1996, 153. 
Institute (PHI) and by the Centre de Traitement Electronique des Documents (CETEDOC) ${ }^{12}$ and second, the concordances that have become increasingly available, partly as a result of such databases. These new resources have helped shift an article's emphasis from Vollmer's preferred model - the primarily rote replication of data in the archives - to the arrangement and interpretation of those data in a manner that is both clear and, inasmuch as possible, objective.

In the following comparison between anteeo 1901 and anteeo 2007, I focus on those aspects that display change most dramatically: the accuracy of citation, the degree to which an article presents morphological and textual variants, and, perhaps most significantly, the subgrouping of material according to grammatical, syntactic, and/or semantic criteria. In addressing each topic, I shall make reference to three appendices, which themselves constitute the principal contribution of this article: (A) a comparison of the skeletal frameworks of the 1901 and 2007 entries; (B) the complete version of anteeo published in 1901; and (C) the 2007 rewrite.

I begin with the most mechanical as well as the most readily appreciated improvement. Dr. Peter Flury, editor-in-chief at TLL from 1974 to 2001, has compiled comparative statistics on the accuracy of citations and quotations in the lexicon (personal communication). In a sample drawn from the 1984 "P" volume (X 1 and X 2), he found that approximately every sixty-third citation contains some type of mistake, such as an incorrect reference to the work cited or an inaccurate quotation of the Latin text. Articles written in the 1930s contained errors in every seventeenth citation, that is, with almost four times greater frequency. Dr. Flury did not conduct such a study on the earliest volumes, but for the 137 textual references in the original anteeo (a sample smaller than that of Flury's study by about one-eighth), I have found twenty-three errors, an average of one for every sixth citation. From one error in six in 1901 to one in sixty-three in 1984 represents a significant improvement in quality control. And with the nearly universal use of word-processing at the institute and the recent capability for the dictionary's publisher to produce volumes directly from disk, one would expect an even higher degree of accuracy in those fascicles produced since 1984. It should also offer some sense of comfort to users of the recently released Electronic TLL that the digital transcription of Bannier's anteeo introduced only one new error to this number (nu for upsilon in a Greek citation at vol. II 147, 76). (Note: in all

\footnotetext{
${ }^{12}$ For this article I used PHI disk 5.3 and the online version of CLCLT-6 (consulted March 2006).
} 
references to articles published in TLL, I follow the accepted convention; here, "volume II, page/column 147, line 76." $)^{13}$

Bannier's article also contains more serious inaccuracies. Despite the manifold obligations of its author, however, anteeo 1901 does not contain any of the egregious mistakes that have become a minor source of embarrassment in Munich. It is unlikely that the careful quality control currently practiced at TLL would allow the type of misreading found under the lemma contentus, where Valerius Flaccus's contenti vellere (8.178) is construed not as "contentus plus ablative" ("content with the fleece"), but as "contentus plus infinitive" ("content to pluck"; vol. IV 680, 23). One could also mention the misinterpretation of Hercules Oetaeus 851 to which Housman refers in his Manilius commentary. ${ }^{14}$ In asking Jupiter to destroy her, Deianira cries "[me] pestem ut insolitam feri" ("strike [feri] me, like an extraordinary curse"). The TLL has listed the passage not under the verb ferio, but as an example of the substantival use of the noun ferus (apparently "like the extraordinary curse of a wild animal"; vol. VI 1 606, 60).

In preparing the rewrite, I had access to more raw material than my predecessor. This new material derives from two basic sources: first, the addenda that have been collected on new slips since the original article appeared in print, cataloguing both overlooked occurrences of the lemma in primary texts and specialized discussions in the secondary literature; and second, searchable electronic databases and recently published concordances of individual authors and corpora. Among the addenda occurs a passage from Terence's Andria where anteire means "prevent." This passage predates by two centuries Bannier's earliest example for this meaning from the poet Grattius (appendix C, lines 112-13). It is possible to reconstruct the reasons for this omission. The original excerptor of Terence in the 1890s, following the 1884 Teubner edition of Karl Dziatzko, had recorded the lemma as two words in tmesis-ante eamus; as a result, the completed slip was filed under the simplex verb form eo, ire (with a separate slip filed under ante). ${ }^{15}$ The oversight

${ }^{13} \mathrm{~A}$ similar level of accuracy, using a larger range of data, is noted in the reviews of the third (Heslin 2006) and first editions (Lühken 2003). K. G. Saur Verlag made no attempt during the digitizing process to correct preexisting errors in the printed edition.

${ }^{14}$ Housman 1937, 10 (ad Manil. 5.77): "feros, equos, cuius usus novum ac mirum exemplum thesaurus ling. Lat. ... profert ex Sen. H.O. 851."

${ }^{15}$ Oskar Hey, the author of ante, postpones discussion of this alleged Terence example to his entry on ante quam (vol. II 128, 74: "v. sub ante quam"); but in the latter article, Hey, mysteriously, does not cite the Terence passage (it would have been particularly appropriate at vol. II 159, 4, where he lists cases in which ante is used pleonastically with prius). 
lay undetected until Hans Rubenbauer began work on eo, ire over thirty years later, whereupon the slip was duly re-filed among the addenda for anteeo. It was among these addenda that I first found a reference to Terence Andria 556. Although Bannier was not involved in the production and filing of the original slip from Terence, he nevertheless should take some responsibility for the omission. Not only does Forcellini's Totius Latinitatis Lexicon cite the Terence passage s.v., but both Georges and Klotz-the standard German lexica of the day-do so as well, as does Nettleship 1889, to whose discussion Bannier had a reference among the original slips. And, incidentally, contrary to what one might expect, the computer age would not have saved Bannier. If someone today were to search the PHI disk under the letter sequence A-N-T-E-E, this Terence passage would remain hidden, since anteeamus continues to be printed with a word break in the standard modern editions.

In addition to this citation from Terence's Andria, other material found in the addenda has been incorporated into anteeo 2007. A passage from Ausonius, for example, offers an exception to Bannier's statement that the second and third syllables of anteeo are always contracted in the poets (appendix B, pp. 147, lines 48-49: apud poetas semper per synaloepham legendum est. The restatement can be found in appendix $\mathrm{C}$, lines 13-15, under the rubric de prosodia). In other places the addenda for anteeo simply supplement examples of meanings already found in the original material. The number of addenda to anteeo available to me, however, would be significantly smaller than that for, say, a word beginning with the letter "T," a letter for which articles have not yet been written and whose lemmata are, consequently, supplemented more methodically than those that have already appeared in print.

Lexicographically significant uses of anteeo from the second to sixth centuries C.E. could, therefore, still lie hidden. It is at this point that I depart from Bannier's methodology to turn to digital resources. As it turns out, technological advances in information retrieval had little impact on rewriting anteeo in the twenty-first century. A search of the PHI disk yielded no new material for the period up to Apuleius, the period for which the Thesaurus archive claims completeness. This search did find two later passages_-from Gellius (1.1.3) and Servius (ecl. praef. 1. 83) - that were not in the archival material. Neither passage proved to be lexicographically significant, a result that one might be tempted to attribute to chance; but it is equally legitimate to credit the apparent comprehensiveness of the archive to the labors of both those scholars who excerpted the material from the third through sixth centuries and those who have compiled addenda since the article appeared in print. Hence the results 
of searching the PHI database strengthen a user's confidence that even an early Thesaurus entry will contain the most important extant evidence available for obtaining a complete understanding of the lemma.

The far more expansive CLCLT database provides additional support for this claim. A search for occurrences of forms of anteeo within the category of texts searchable in CLCLT for the period up to 500 C.E. yields approximately sixty hits, of which twenty-two are not in the archival material. Of these twenty-two instances, nearly all correspond to the earliest and most commonly attested meaning of the verb- "to excel in some quality." Only one passage would merit inclusion in the rewritten piece, an excerpt from Calcidius's Latin commentary on Plato's Timaeus from the late fourth or early fifth century: decem et octo numerus sex numerum triplo anteit ( 46 p. 96, 11: "the number eighteen exceeds the number six by threefold"). The context also offers praecellit as a clear synonym for the lemma (anteeo 2007, line 36 offers the same juxtaposition of synonyms). Were this passage to be included in the article, it would fall in section IA1b, where there is currently no precise parallel for the verb anteeo taking the accusative in describing how something is superior in quantity (but cf. line 91, with a parallel sense but not syntax, or the analogous lines 39-41). The presence of approximate parallels such as these ensure that a reader encountering this Calcidius passage could readily construe its sense from the TLL entry even if the passage is not included in the article.

It is clear from the remarks thus far that the major advances at the Thesaurus since 1901 do not proceed from the writers of articles having access to a larger database. Nor do the higher standards in quality control, as impressive as they are, mark the most significant improvement. Rather, the contemporary user of TLL benefits most from the increasingly sophisticated lexicographical methods that have been adopted in Munich over the past hundred years. Starting from the old and new versions of anteeo given in appendices B and C, I shall now discuss three separate areas in which these developments manifest themselves. The areas include: first, the preliminary paragraph preceding the body of the Thesaurus article; second, the skeletal framework in which the primary material is presented; and third, the parenthetical remarks one finds in the article itself.

An immediate difference becomes clear before the reader even reaches the lemma. Introducing anteeo 2007 is a symbol resembling an asterisk - the so-called Zigarre ("cigar"). This symbol, initiated with the "C" volume, indicates that the subsequent article contains only a selection of the occurrences of the lemma found in the Thesaurus archive. While Bannier did include most of the material that had been collected by the 
time of composition, he did not include all; nowhere, however, does his article reveal that the passages given represent only a selection of those known to him. Anteeo 2007, by contrast, makes clear from the outset that what follows offers select examples only and, within the article proper, abbreviations such as al. (alia) are employed to mark where at least one additional example can be found in the material. ${ }^{16}$ This refined use of al., however, does not alleviate all frustrations for the user. Not only is it impossible to tell how many passages lie hidden behind an innocent looking al. (the number may range from one to countless dozens), but the abbreviation can also provide a convenient repository for occurrences of the lemma whose precise meaning cannot be recovered from the extant context and for which a lengthy discussion would use up valuable space in the printed volume. ${ }^{17}$

The lemma introduces a preliminary paragraph, or Kopf. For all but the smallest modern TLL entries, the Kopf displays various types of information that normally have only indirect bearing on the word's semantic range and so cannot be presented conveniently in the article proper. Included are notes on prosody, as we have seen, as well as on orthography, morphology, textual variants, and even literary history. Etymologies are given immediately after the dictionary form of the lemma. Here the origin of anteeo is obvious (appendix C, line 1, where an editor simply supplied " $a b$ ante ...et ire"); in less apparent instances, these etymologies are prepared outside the institute specifically for TLL by a professional Indo-Europeanist. The subsections of anteeo 2007 entitled scribitur and legitur provide two particularly clear examples of the increased attention that the modern TLL gives to representing the non-semantic history of the lemma. In the original anteeo, Bannier records from Plautus the orthographic variant antideo and lists six examples (appendix B, p. 147, lines 47-48). One may here contrast the scribitur portion of the new article-the rubric under which a user of the present-day Thesaurus will find all such matters of ancient orthography. In anteeo 2007, a distinction is made between those passages in which the orthographical variants antidit and anteidibo are attested by the fifth-

${ }^{16}$ See, too, the notation "exempla selecta inde a TAC." (appendix C, lines 29-30). In the early volumes, indications of when and where authors chose not to include archival material in the published article occurred only sporadically and with inconsistent terminology (al., saepius, passim, etc.). Consistency, in particular with al., was not established until the 1930s (Flury 1995, 50-52).

${ }^{17}$ Kröner 1975, 102-3, discusses analogous problems facing scholars who attempt the daunting task of writing a critical review of the lexicon. 
century Ambrosian palimpsest (codex A) and those that occur as variant readings later in the tradition (appendix C, lines 1-3). Specific reference to codex A makes clear to users where this spelling is attested before the sixth century C.E., the period normally covered by the lexicon. The rubric scribitur also covers orthographic peculiarities not mentioned by Bannier. To illustrate possible variations in the lemma's pronunciation, anteeo 2007 includes an inscription that transmits anteire as two separate words written consecutively, as well as examples of an opposite phenomenon, namely, those instances in which the final syllable of the preverb is omitted, resulting in such forms as antire or antisse (appendix C, lines 3-5). A second addition of the rewrite is the legitur section, which Bannier chose not to include (lines 15-17). The greater amount of material available in 2007, however, allows the new article to stress the word's appearance in our earliest sources-in both poetry and prose-and to contrast the ascendancy of praeire over anteire in later Latin texts (Augustine, for example, uses anteire only ten times, but praeire fifty-six; Gregory the Great shows a similar preference for praeire in the proportion of six to fifty-eight). In 1901, Bannier could not have hazarded such a statement for a number of reasons: the unmethodical excerption of texts later than the second century C.E.; the absence of resources such as the Augustine lexicon project or the Gregory concordance; and, of course, the fact that praeire had not yet been written. ${ }^{18}$ The Kopf of anteeo 2007 concludes with a section in square brackets, a section typically introduced with words such as trad(itur) or confund(itur) c(um): "[falso trad. anteamus pro antea mos ARNOB. nat. 5, 41]" (appendix C, lines 17-18). This final portion of the preliminary paragraph, regularly present in recent fascicles, indicates places in the textual tradition where the lemma is confused with another word (or other words). In this particular instance, the extant textual tradition of Arnobius incorrectly transmits the reading anteamus where context makes clear that Arnobius must have written antea mos. In the Kopf of the rewrite, therefore, the reader encounters several ways in which the article strives to present more comprehensively those aspects of the lemma that lie outside what one would strictly define as the word's "meaning."

Appendix A presents the skeletal framework (Disposition) of the old and new versions of anteeo. A systematic comparison of these frameworks demonstrates that each of the corresponding sections of the two articles

\footnotetext{
${ }^{18}$ The Gregorius Magnus concordance (on microfiche) is included in the Corpus Christianorum series of his complete works; figures on Augustine were obtained upon Peter Flury's request from the Augustinus-Lexikon project based in Würzburg.
} 
contains much the same material (for example, the three main parts of section I subgrouped under proprie in the 1901 article match closely in content sections IIIA1-3 of the rewrite). The descriptions of each section and their internal organization differ greatly, however, and these changes offer additional information to the user. The 2007 framework strives to construct privative oppositions, especially in pairs, so that the user may grasp as easily as possible the article's basic organization. The overarching principle of division is represented by Roman numerals: the fundamental notion of "going forward" underlying all uses of anteeo is divided according to whether the "priority" expressed is predominately qualitative (I), temporal (II), or spatial (III). One can readily appreciate the improved comprehensibility of these distinctions in comparison with the older article's assignment of approximate Latin synonyms. The description in Roman numeral III of anteeo 2007-[praeire, praecedere] praevalente respectu loci ("[to go past] in a primarily spatial sense") - is easier to comprehend quickly than the corresponding description in the older version's Roman numeral I-proprie praeire ("to go past literally").

Both parts of Bannier's formulation here raise problems of interpretation. First, questionable assumptions underlie the use of proprie: why should it be more "literal" to advance spatially than temporally (reserved for his section II, tempore praeire), and what evidence is there that the Romans agreed with this conception? Second, Bannier simply glosses the lemma anteire with the apparent synonym praeire, tacitly assuming that the meaning of praeire is clear to the reader. The frequent practice in the early volumes of simply offering synonyms for a lemma becomes particularly problematic in this instance. The TLL's recent article on praeeo demonstrates that both the earliest and the commonest meaning of this verb has in fact little to do with spatial progression (vol. X 1595 , 41-596, 4). By contrast, note the caution in the formulations for anteeo 2007, parts I-III. Rather than committing to one precise meaning for each attested use of the verb, the rubrics are said to include passages where a particular sense "prevails" (praevalente respectu). Through this periphrasis, the contemporary TLL keeps the reader aware that for any given instance of anteeo in section III, other aspects of movement may be implied beyond the spatial (for direct signposting to the reader of this possibility see, e. g., lines 69 [vergit ad IIA2] and 142 [an ad B? vix ad 2]). In its skeletal framework, then, the modern TLL succeeds in three important objectives: (1) through the concept of privative oppositions, separate semantic realms are constructed so as to avoid as much as possible any potential overlap between them; (2) the resulting organization provides helpful signposts for readers in their search for particular nuances of the 
lemma; and (3) the lexicon avoids dogmatic assertions, in accordance with its stated wish not to be considered oracular or definitive.

Another important change in methodology becomes clear from a comparison of the order in which passages are presented within each article's skeletal framework. For each section and subsection of an article in TLL, it has always been institutional practice to order citations chronologically; violation of this order is clearly signaled by the use of parentheses and brackets. This ordering principle did not always apply, however, to the relationship between individual sections. In the early volumes, authors tended to list the material as Bannier had for anteeo (appendix A), where the literal uses (I proprie) precede the figurative (II translate), despite the fact that the earliest attested uses of the figurative meaning in Plautus antedate by several decades the first known literal use in Lucilius. In recent volumes, however, it has become the rule to order chronologically the individual sections as well. Hence, in anteeo 2007, examples of priority in respect to some abstract quality or rank (a usage that is arguably figurative) are listed before those describing precedence in space or time, since the former meaning is the earliest attested. This shift in practice is consistent with a principle already mentioned, namely, that the TLL aims as much as possible to be an historical and descriptive lexicon, leaving it to the user's initiative to decide what possible significance could be attached to the phenomena that each article describes. And yet this desire to appear more objective has its own cost. In the article lepus, leporis ("hare"), adherence to the principle of chronology led its author to devote forty-two lines of text to describing the use of the animal in analogies and figures of speech (e.g., "they flee more swiftly than a hare") before turning to references to the living animal itself. The counterintuitive nature of this listing prompted one reviewer to note: "if one were to interpret precisely the history of the word as offered here, then the Romans must first have learned of the hare only from hearsay before they encountered it in reality." ${ }^{19}$ In many cases, nevertheless, retaining the chronological order prompts the careful user to reflect on what significance such apparent deviations from expectations may have for an understanding of Roman culture; consider, for example, the adjective pravus, where the apparently "literal" meaning ("bent, crooked") is attested relatively late and less often in the word's history in comparison with its ubiquitous figurative use in describing

\footnotetext{
${ }^{19}$ Kröner 1975, 107 ("Wollte man die hier vorgelegte Wortgeschichte genau interpretieren, so hätten die Römer den Hasen zunächst nur vom Hörsagen, dann erst in der Wirklichkeit kennengelernt"); in response, see Flury 1995, 36-37.
} 
moral "crookedness." The literal meaning, accordingly, appears second in the Thesaurus article. ${ }^{20}$

Perhaps the single most distinctive advance in the Thesaurus's attempt to convey the lexical history of a lemma as objectively as possible is in the careful deployment of parenthetical remarks (Klammerbemerkungen). Such remarks, designed to organize internal sub-groupings and to supply cross-references to other parts of the article (or to other entries in the lexicon), barely occur in Bannier's version, and, where they do, the reader receives no indication of the logic behind groupings (e.g., at 147, 54 , or 148,20$)$. Anteeo 2007 , by contrast, attempts to guide the reader and, in so doing, demonstrates well the types of information that can be conveyed through this helpful shorthand. In the framework developed for the rewrite, grammatical considerations often determine the lowest levels, with citations grouped according to whether anteeo governs a dative, an accusative object, or some other construction (appendix A, IA1 and 2; IIA1a and b; IIIA1, 2, and 3). This organization developed out of the material, of course, but the decision to divide the article accordingly was ultimately made by the author and editors, a subjective choice that users of the lexicon need always bear in mind. In such a process of division, here by grammatical criteria, the lexicon inevitably simplifies, and so risks straitjacketing Latin's vocabulary. In attempting to isolate one specific meaning for each passage in the material, the article has the potential to deny the possibility that in the original context the Latin author exploited a lexeme's ambiguity for poetic or rhetorical effect.

Parenthetical remarks serve as a precaution against such an overly subjective arrangement by suggesting, among other functions, alternative ways in which one could organize the same material. In the case of anteeo, these remarks indicate ways in which to group the passages thematically rather than grammatically. For example, in section IIIA3 (appendix C, lines 165-67), Tacitus's Histories 2.5.1 appears as an instance of anteeo taking an accusative object of the "person or thing following" (quis [quid] sequatur indicatur per acc.). In the subsequent parentheses, two parallel passages are cited where the verb anteeo describes, as in Tacitus, leadership in a military action. Although these three texts share no verbal echoes other than the lemma itself, their common semantic realm has determined their grouping, as is made explicit through the editorial note "likewise about military leaders" (item de ducibus militaribus, where ducibus is printed with expanded character spacing to indicate that in each text some type

${ }^{20}$ For one reading of the meaning of pravus, see Monteil 1964, 241-60. 
of military commander, though not necessarily designated explicitly with the word $d u x$, is the subject of the verb). Within this same parenthesis occurs a second typical use of bracketing. Following the citation of Ammianus 16.12.24, square brackets indicate that in the surrounding context the historian had used the verb agebat synonymously with the lemma. References such as this are designed to meet the express desire of the lexicon to allow the texts themselves to illustrate meaning whenever possible. Yet another way of representing synonyms can be found a couple lines later in the new article (lines 169-71), where a parenthetical note indicates that Solinus, in paraphrasing a statement of the elder Pliny, uses the verb anteire to represent the ducere of his source ("sec. Plin. nat. 10, 126, ubi ducere"). Again, in contrast with the 1901 version, the parenthetical remark succinctly indicates ancient perceptions of the semantic range of anteeo.

This final example suggests an inevitable byproduct of increasing sophistication: any attempt to be simultaneously comprehensive and concise must occasionally lead to confusion. It is not uncommon to hear protests from first-time users of the lexicon about the bewildering array of brackets, parentheses, and abbreviations, not to mention the unfamiliar idiom of specialized Latin used for explication by an article's author. In the phrase just mentioned, for example ("sec. Plin. nat. 10, 126, ubi ducere"), a casual user may well puzzle over the abbreviation "sec." or over why "Plin. nat. 10, 126" is printed in italics while "ducere" is not. It perhaps offers small consolation to the casual user that each of these practices follows well-established TLL convention (namely, "sec." = "secundum"; a citation in italics indicates that the lemma does not occur in that passage; Latin words printed in upright type are attested in an ancient text-that is, in this case ducere, not anteire, is the verb Pliny used). Despite this established tradition, however, is it too radical to suggest that TLL consider composing the commentary portions of its text in a modern vernacular, as Stephens has recently suggested for critical editions of Greek and Latin texts? ${ }^{21}$ Precedents do exist. Analogously comprehensive Latin dictionaries now use modern languages for scholarly exegesis, in particular the most important works that have been produced to update Du Cange's Glossarium Mediae et Infimae Latinitatis. ${ }^{22}$

${ }^{21}$ Stephens 2002, 70-71.

${ }^{22}$ The Dictionary of Medieval Latin from British Sources uses exclusively English for glosses, the Mittellateinisches Wörterbuch German and Latin, Niermeyer's Mediae Latinitatis Lexicon French, English and German, and the non-regional Novum Glossarium Mediae Latinitatis only French. 
A second example from the rewrite demonstrates how excessive concision may even mislead. Tacitus uses the verb anteeo three times to describe an individual committing suicide as a way of "anticipating" death at the hands of the emperor. In appendix C, lines 116-18, these testimonia receive the gloss [anteire] morte voluntaria ("to anticipate by suicide"). This grouping is useful, although perhaps only an experienced user will realize that the absence of other parallels in the parentheses indicates by its silence that Tacitus is the only author in the archival material to use the lemma in this particular sense. An instance of sub-bracketing in this passage, furthermore, may confuse the infrequent user by its very concision. Even if equipped with the helpful key given in the Praemonenda $(1990,33)$, it requires some thought to unpack the concise remark "6, 29, 4 damnationem [13, 30,1 veneno]." To an experienced user, it would be clear that Tacitus had written at Annales 13.30 .1 something like veneno damnationem anteire. In adopting such an admirably concise format, therefore, the dictionary may sacrifice immediate clarity.

A second difficulty complicating the relationship between TLL and its readership concerns one of its basic principles. Understandably, the lexicon prefers, whenever possible, to represent Latin usage not from a modern perspective but from that of its native speakers. This is a sound policy in theory, but an example from the rewrite illustrates how strict adherence to this principle risks misleading contemporary users of the dictionary (appendix C, lines 131-32). Rufinus, in translating Eusebius into Latin, has been discussing the different types of information with which he must preface his narrative history. The verb he uses for this act of "prefacing" is anteire. The question immediately arises for the composer of the article of where to place this passage in the skeletal framework. In other words, does precedence in a written text denote priority in time (section II) or in space (section III)? Such a problem is not a new one at the Thesaurus, and the institute has long had a solution. Precedence in a text is temporal. The argument runs as follows: since in the ancient world the spoken word predominated over the written, the act of not only reading but also writing was considered to have primarily a temporal and not local significance. Hence the citation from Rufinus now resides in section IIB: [praeire, praecedere] praevalente respectu temporis ("to precede in a predominately temporal sense"). The modern user of TLL, however, wishing to discover whether the Romans ever used anteeo to describe priority in writing, will quite likely search in section III, where the rubric [praeire, praecedere] praevalente respectu loci ("to precede in a predominantly spatial sense") describes the way most moderns view the relationship between words in a text, particularly in an age when the 
physical transposition of texts can be done with the click of a mouse. Often in cases like this, but not always, the author of an article will include a cross reference (in this instance in section III), warning the reader of where such ambiguous passages have been placed in the article. Here we have an example for which it is difficult to decide whether antiquarian accuracy balances out the potential for misunderstanding. The position of the institute is, moreover, not unassailable; Bettini provides compelling arguments for believing that Romans perceived of movement in time as primarily spatial. ${ }^{23}$

A third difficulty the scholar faces in using TLL is more theoretical. The "objective" lexicographer represents always a never-existing ideal. Nevertheless, writing in a specialized, traditional, and seemingly objective Latin code assists in endowing the author of each article with a status that helps render individual subjectivity invisible. ${ }^{24}$ While the institute acknowledges single authorship by including names at the end of each entry, and by requesting that scholars include author's names when citing entries from the lexicon, the subjectivity of that author disappears in the columns themselves: see in the rewrite, for example, ex cathedra pronouncements such as vix addas (line 14) or abl. instr., vix dat. intellegas (line 152), each of which implies an alternative explanation for an occurrence of the lemma (or else why mention it at all?) that is "hardly" (vix) worth considering. Kaster has recently offered several excellent examples of how asking different questions about a word, ones perhaps not strictly lexicographical, reveals aspects of the lemma that cannot easily be contained in a dictionary article. ${ }^{25}$ The TLL, despite its comprehensiveness, can never offer the last word on a word. At TLL, after more than a century of work with a full-time staff, these issues of fallibility have long been familiar; nevertheless, the apparent smoothness and sheer monumentality of the published work can give a quite different impression to the user.

I would like to conclude with a positive observation concerning Wilhelm Bannier's original article. Despite the undeniable gains in sophistication made over the course of the twentieth century, it is some consolation that all the efforts made to improve how an article speaks to the user does not erase the fact that anteeo 1901 contains nearly all the material in the archives. For someone with the interest and leisure to read

\footnotetext{
${ }^{23}$ Bettini 1991, 115-20.

${ }^{24}$ Compare Kraus 2002, 2-6, on the "professional fiction" of the invisible scholarly commentator of Greek and Latin texts.

${ }^{25}$ E.g., Kaster 2006, 85-86, on invidia.
} 
through the entire article carefully, many of the basic principles found in the 2007 rewrite are available in the original for excavation. From this perspective, however, the original article functions hardly differently from a modern database, and databases abound nowadays. It would be foolish to deny that the recent fascicles of TLL, which interpret and classify this data for the reader, provide far more useful information than their earliest ancestors. The differences in version 2007 represent, therefore, significant improvements: increased accuracy of citation, the resources of digital databases, clearer and more flexible principles of organization, and increased sensitivity to non-semantic characteristics of the lemma. Such factors, however, also result in a much slower pace of production and risk transforming the Thesaurus from a tool accessible to anyone with knowledge of Latin to an instrument with a language and organization accessible only to experienced and trained specialists. We are fortunate that the editors at the institute and the members of the Internationale Thesaurus-Kommission continue to remain sensitive to these issues, balancing the desire for accuracy with the need to finish the lexicon, while at the same time striving to remain true to the principle that, in spite of the decades of labor that have gone into producing the lexicon, the ultimate objective remains - as paradoxical as it may sound-to allow a dead language to speak for itself. ${ }^{26}$

UNIVERSITY OF KANSAS

email: corbeill@ku.edu

\section{ABBREVIATIONS}

CLCLT $=$ 2005. Library of Latin Texts, 6th ed., available by subscription via www.brepolis.net.

Electronic TLL = 2005. Electronic Thesaurus linguae latinae. 3d ed. Munich: K.G. Saur Verlag.

${ }^{26}$ I am grateful to Kathleen Coleman for suggesting that I publish this after it lingered for a decade in a filing cabinet and for her careful critique. Nicholas Horsfall, Jim McKeown, and an anonymous reader for $A J P$ offered helpful comments on a penultimate version. Two scholars and friends were my coauthors. Cornelis van Leijenhorst offered patient criticism and innumerable suggestions from 1991 to 2007. Any part of this article that may be worthy of Peter Flury's knowledge, encouragement, and friendship I dedicate with the deepest gratitude to his memory. 
Index $(1904)=1904$. Thesaurus linguae latinae. Index librorum scriptorum inscriptionum ex quibus exempla adferuntur. 1st ed. Leipzig: Teubner Verlag.

Index $(1990)=1990$. Thesaurus linguae latinae. Index librorum scriptorum inscriptionum ex quibus exempla adferuntur. 2d ed. Leipzig: Teubner Verlag.

PHI disk $=$ Packard Humanities Institute CD of Latin authors, version 5.3.

Praemonenda $=1990$. Thesaurus linguae latinae: Praemonenda de rationibus et usu operis. Leipzig: Teubner Verlag.

\section{BIBLIOGRAPHY}

Beikircher, Hugo. 2005. "Der Fluch der Vollständigkeit." Akademie Aktuell. Zeitschrift der Bayerischen Akademie der Wissenschaften 3:62-63.

Bettini, Maurizio. 1991. Anthropology and Roman Culture: Kinship, Time, Images of the Soul. Trans. John Van Sickle. Baltimore: Johns Hopkins University Press.

Bögel, Theodor. 1996. "Beiträge zu einer Historia Thesauri linguae Latinae." In Thesaurus-Geschichten. Beiträge zu einer Historia Thesauri linguae Latinae von Theodor Bögel (1876-1973), ed. Dietfried Krömer and Manfred Flieger, 1-165. Stuttgart: Teubner Verlag.

Flury, Peter. 1987. "Der Thesaurus Linguae Latinae." Eirene 24:5-20. . 1995. "Vom Tintenfaß zum Computer." In Wie die Blätter am Baum, so wechseln die Wörter: 100 Jahre Thesaurus linguae Latinae, ed. Dietfried Krömer, 29-56. Stuttgart: Teubner Verlag.

Forcellini, Egidio. 1858-75. Totius Latinitatis Lexicon, 3d ed. of Giuseppe Furlanetto, rev. by Vincenzo de Vit, 6 vols. Prati: Aldine Press.

Heslin, Peter. 2006. Rev. of "Thesaurus Linguae Latinae," Third electronic edition. Munich: K. G. Saur Verlag, 2005. Bryn Mawr Classical Review 2006.02.19 (http://ccat.sas.upenn.edu/bmcr/2006/2006-02-19.html).

Hey, Oskar. 1996. "Aus den Anfängen des Thesaurus linguae Latinae." In Thesaurus-Geschichten. Beiträge zu einer Historia Thesauri linguae Latinae von Theodor Bögel (1876-1973), ed. Dietfried Krömer and Manfred Flieger, 167-72. Stuttgart: Teubner Verlag.

Housman, A. E., ed. 1937. M. Manilii Astronomicon Liber Quintus. 2d ed. London: Richards Press.

Kaster, R. A. 2005. Emotion, Restraint, and Community in Ancient Rome. Oxford: Oxford University Press.

Kraus, Christina. 2002. "Introduction: Reading Commentaries / Commentaries as Reading." In The Classical Commentary: Histories, Practices, Theory, ed. Roy Gibson and Christina Kraus, 1-27. Leiden: E. J. Brill. Mnemosyne suppl. 232.

Krömer, Dietfried, and Manfred Flieger, eds. 1996. Thesaurus-Geschichten. Beiträge zu einer Historia Thesauri linguae Latinae von Theodor Bögel (1876-1973). Stuttgart: Teubner Verlag. 
Kröner, H.-O. 1975. Rev. of Thesaurus linguae Latinae. Vol.: VII, 2; Fasc.: VIII; lego-liber (adi.). Leipzig: Teubner Verlag, 1974. Kratylos 20:101-8.

Lühken, Henning. 2003. Rev. of "Thesaurus linguae Latinae," First Electronic Edition. Munich: K. G. Saur Verlag, 2002. Göttinger Forum für Altertumswissenschaft 6: 1103-21.

Monteil, Pierre. 1964. "Beau" et "laid" en Latin. Étude de vocabulaire. Paris: C. Klincksieck. Études et commentaires 54.

Nettleship, Henry. 1889. Contributions to Latin Lexicography. Oxford: Clarendon Press.

Stephens, Susan. 2002. “Commenting on Fragments.” In The Classical Commentary: Histories, Practices, Theory, ed. Roy Gibson and Christina Kraus, 67-88. Leiden: E. J. Brill. Mnemosyne suppl. 232.

Stroh, Wilfried. 2005. "Lateinstadt München.” Abschiedsvorlesung, Universität München, Nov. 17,2005. (www.klassphil.uni-muenchen.de/ stroh/lateinstadt _muenchen.html). 
용

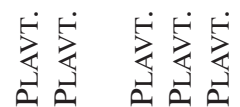

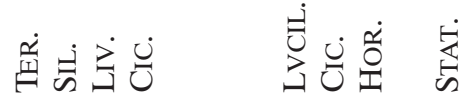

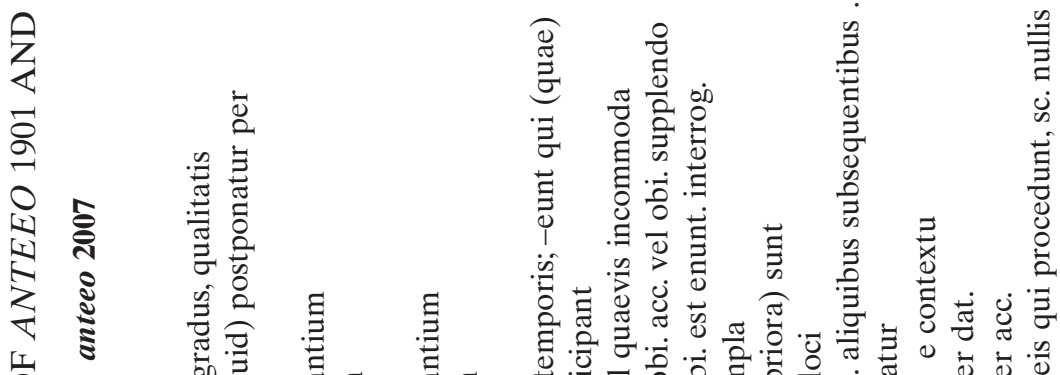

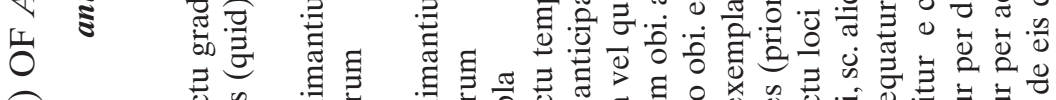

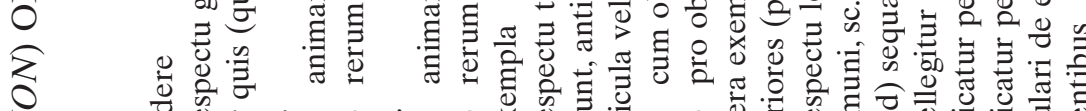

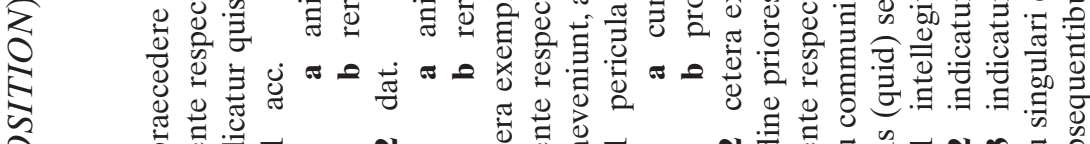

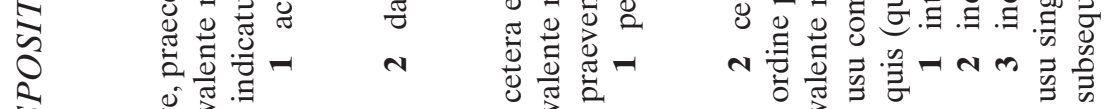

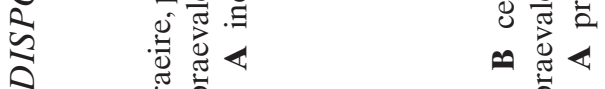

$\vartheta \quad \frac{\pi}{2}$

$\ddot{v} \quad \dot{\sim}$

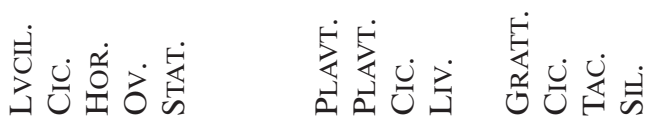

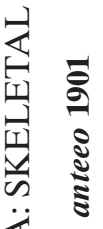

竞

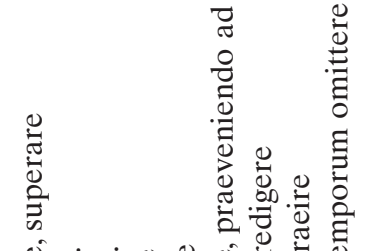

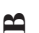

$\stackrel{\pi}{\pi}<$

目

$\sum_{\frac{1}{4}}^{3}$

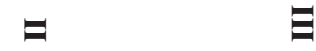

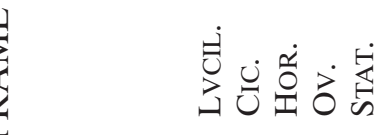

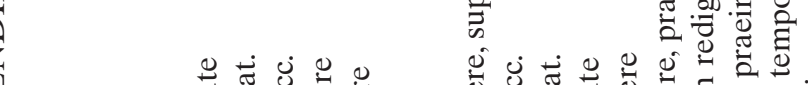

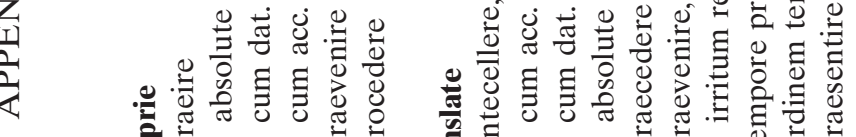

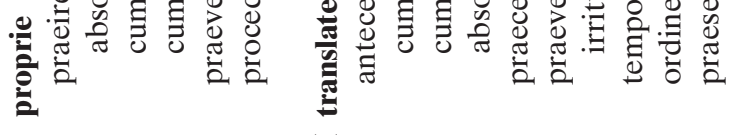




\section{APPENDIX B: ANTEEO 1901 AS PUBLISHED} (TLL VOL. II 147, 42-148, 73)

[p. 147]

anteeo, -iī, -itum, -īre $v$. ео. PRISC. gramm. III 40,17 пеоло-

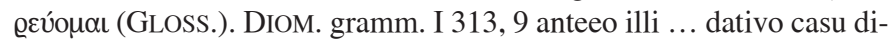
cimus ... anteeo quoque illum accusativo casu (VII 454, 10). PROB. gramm. IV 34, 13 e ante eo posita tertiam productam regit, tempus perfectum ivi vel ii facit, ut anteeo praeeo, anteivi praeivi vel anteii praeii. a n t i d e o PLAVT. Bacch. 1089 (codd. antedeo) Cas. 225 Cist. 205 Persa 778 Pseud. 933 Trin. 546. apud poetas semper per synaloepham legendum est. sim. antire, antiret, antisse, antissent,

50 antibo TAC. ann. (Woelfflin, Philol. 25, 1867, 104). in tmesi LVCIL. 1080 Ov. fast. 6, 117 Pont. 4, 7, 52 STAT. Theb. 6, 485.

I proprie: praeire. absolute: LVCIL. 1080 praetorum est ante et prae ire. CiC. agr. 2, 93 anteibant lictores. off. 2, 25 barbarum ... destricto gladio iubebat anteire (VAL. MAX. 9, 13 ext. 3). LVCR. 4, 138 interdum magni montes avolsaque saxa montibus anteire et ... succedere videntur. HoR. epist. 2, 2, 70 quodsi cessas aut strenuus anteis. Ov. fast. 6, 117 credulus fante iit frutices haec nacta resistit. LIV. 1, 59, 6 ubi anteire primores civitatis vident. 24, 44, 10 cum ... lictores ... taciti anteirent. PAVL. FEST. 244 praepetere dicebant pro anteire.

60 TAC. ann. 1, 64 donec saucii quantumque gravioris agminis anteirent. SVET. Iul. 57 in agmine nonnumquam equo, saepius pedibus anteibat. Aug. 64 nisi ut vehiculo anteirent. cum dat.: CIC. agr. 2, 93 anteibant lictores ... ut hic praetoribus urbanis anteeunt. rep. 2, $31 \mathrm{ut}$ sibi duodecim lictores cum fascibus anteire liceret. cum acc.: HoR. carm. 1,35, 16 te semper anteit saeva Necessitas. Ov. met. 11, 54 nunc praecedentem sequitur, nunc praevius anteit. MANIL. 5, 76 pronum ... anteire volantis. SEN. Ag. 453 anteire naves laetus et rursus sequi. CVRT. 3, 3, 15 hi currum regis anteibant. Plin. nat. 10, 16 lupi minotauri equi aprique singulos ordines anteibant. STAT. Theb. 7, 108

70 Pavorem quadripedes anteire iubet. TAC. hist. 2, 5 Vespasianus ... anteire agmen. PLIN. paneg. $10 \mathrm{cum}$... tua vexilla, tuas aquilas magno gradu anteires. Sol. 2, 46 alter agmen anteit, alter insequitur. LACT. ep. 67 (72) anteibit eum claritas ignea. AMM. 16, 12, 24 anteibat cornu sinistrum. 29, 5, 30 quos anteibant quidam Romani. VVLG. Is.

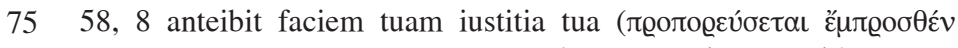
oov LXX). Clavd. 28, 377 ut Massyla tuos anteirent oppida currus. praevenire: OV. ars 2, 725 neque tu dominam ... desine nec cursus anteeat illa tuos. STAT. Theb. 6, 485 tunc ipsum Hippodamum fracto curru deturbat, et isset ante Chromis. TAC. ann. 12, 27 monitos, ut

80 anteirent populatores. hist. 1, 45 anteire proximos, certare cum praecurrentibus. 2, 30 anteire signa, urguere signiferos. GELL. 2, 26, 20 
absque te ... lingua ... Graeca longe anteisset. AMM. 27, 6, 10 milites alius alium anteire festinans. procedere: STAT. Theb. 10, 394 miseri pergunt anteire.

\section{[p. 148]}

II translate: antecellere, superare. cum acc.: PLAVT. Bacch. 1089 omnis longe antideo (antedeo codd.) stultitia et moribus indoctis. ibid. frg. 15 hic adulescens multo Vlixem anteit. Cas. 225 munditiis munditiam antideo. Cist. 205 qui omnes homines supero [atque] antideo cruciabilitatibus animi. Pseud. 933 te dolis atque mendaciis ... antidibo. Trin. 545 Campans genus ... Surorum ... antidit (codd. et NON.: anteit DIOM. gramm. I 313) patientia. TRABEA com. 5 Fortunam ipsam anteibo fortunis meis. TER. Phorm. 247 quantum erum ante eo sapientia. RHET. Her. 3, 6, 11 ipsa facta ... eloquentiam anteire.

10 Cic. Brut. 229 consulum, qui omnis intellegentia anteibant. Sulla 23 nec se aequales ... abs te anteiri putant. Phil. 9, 1 cum ... aetate illos anteiret, sapientia omnis. ac. 1, 35 cum ... Arcesilam anteiret aetate. nat. deor. 2, 153 hominis natura quanto omnis anteiret animantes. Att. 12, 31, 2 quod summum pretium constituam et quan-

15 tum anteire istos hortos Drusi. BELL. Alex. 38, 4 multum numero anteibat nostrum equitatum. SALL. Iug. 6, 1 cum omnis gloria anteiret. or. Phil. 13 boni malos facile anteibant. hist. 1, 75 qui aetate et consilio ceteros anteibat. NEP. Thras. 1, 3 cum eum nemo anteiret. Chabr. 4, 1 omnes ... auctoritate anteibat. VERG. Aen. 12, 84 qui (equi)

20 candore nives anteirent, cursibus auras (SIL. 13, 116). PROP. 1, 16, 19 patrui meritas conare anteire secures. 2, 3, 41 si quis vult fama tabulas anteire vetustas. Ov. met. 13, 366 quanto ... ratem qui temperat, anteit remigis officium ... tantum ego te supero. Pont. 4, 7, 52 tantum virtus alios ... praeterit ... ante citos quantum Pegasos ibat

25 equos. LiV. 6, 30, 3 quod ... gratia Iulium anteibant. 6, 34, 7 quo a proximis quisque minime anteiri vult. $28,9,11$ quantum merito anteibat, tantum honore collegae cesserat. 35, 25, 7 omnes ... prudentia et auctoritate anteibat. 39, 40, 3 omnes patricios plebeiosque ... Porcius longe anteibat. SEN. dial. 1, 3, 14 grave est a deterioribus honore 30 anteiri. benef. 3, 36, 1 virtus ... anteire priores cupit. epist. 90, 31 cursu omnes anteibit. SIL. 2, 248 certant annos anteire labore. 5,352 unguere vulnus ... ferrumque ... exigere et somnum misisse ... anteibat cunctos. 16, 561 ventos anteire lacerto. STAT. Theb. 3, 156 Ogygias titulis anteire parentes. 3,182 doctas anteire canendo Aoni-

35 das. 7, 339 Cydoneas anteibunt gaesa sagittas. TAC. ann. 3, 1 comitatum Agrippinae longo maerore fessum ... anteibant. 3, 30 multos triumphalium ... potentia anteiit. 3, 47 dum anteire ceteros parat. 66 suasmet ipse spes antire parat. 3, 75. 4, 40.11,17. 15, 18 et 50 dial. 36 hist. 1, 87. 2, 76 et 101. 3, 38 et 65. 4, 7 et 13. ann. 14, 11 
40 Neronis immanitas omnium questus anteibat. GELL. 19, 9, 8 cedere ... vobis debui ut ... asotia ... Alcinum vinceretis ... ita in cantilenarum quoque mollitiis anteiretis. IVST. 1, 2, 6 quod mulier ... virtute ... viros anteiret. 1, 3, 2 quod mollitia corporis ... omnes feminas anteiret. АMм. 27, 4, 14 agrestes nos anteire. 28, 4, 31 ut velocitate

45 currus ipsos anteeant. AvG. civ. 8, 4 cum ingenio ... longe suos condiscipulos anteiret. 18, 37. MART. CAP. 9, 908 qui omnes ... suavitatum dulcedines anteibat. CARM. epigr. 1177 volucris ante ire vagas (cf. Bücheler ad l.). cum dat.: Plavt. Amph. 649 virtus omnibus rebus anteit. Persa 778 ego omnibus antideo. Cic. Tusc.

501,5 qui iis aetate anteibat. off. 2, 37 qui anteire ceteris virtute putantur. fin. 5, 93 quamvis minimam praestantiam animi omnibus bonis corporis anteire dicamus. TAC. ann. 5, 3 neque Seianus audebat auctoritati parentis antire. GELL. 1, 22, 10 quod copia ... et facultate ceteris anteiret. AvG. civ. 15, 9 gigantes longe ceteris

55 anteibant. absolute: CIC. Lael. 69 quod is anteibat aetate. CAES. civ. 1, 32, 8 ut operibus anteire studuerit. SIL. 9, 436 viri dextra ... pares, sed cetera ductor anteibat Latius. TAC. ann. 2, 43 quia claritudine materni generis anteibat $(12,6)$. hist. 3, 31 ut quis ordine anteibat. GELL. 20, 5, 8 quippe ... doctrina anteire malim quam

60 copiis. Sol. 15, 3 quanto quis anteit, tanto propensiore nota tinguitur (MELA 2, 1, 10 praestare). praecedere LIV. 38, 51, 11 aetatem meam honoribus vestris anteistis. HIER. epist. 79, 2 inter ... honorum culmina, quae aetatem anteibant. praevenire, praeveniendo ad irritum redigere: GRATT. 385 antire auxiliis rabiem canum. VAL.

65 FL. 1, 31 anteire metus. SIL. 13, 617 insidias anteire laborans. TAC. ann. 5, 6 antibo periculum. 5, 10 quo vera seu falsa antiret. 6, 29 damnationem anteiit. 15, 38 incendium anteiit remedia velocitate mali. APVL. met. 4, 2 conatus fortunae meae scaevitatem anteire non potuit. tempore praeire: CIC. fat. 44 si concedunt anteire visa. TAC.

70 ann. 3, 69 ut si antissent delicta, poenae sequerentur. ordinem temporum omittere: TAC. ann. 4, 71 avebat animus antire statimque memorare exitus. praesentire: SIL. 14, 455 quid Boreas, quid vellet crastinus Auster, anteibat.

[Bannier.] 


\section{APPENDIX C: ANTEEO 2007 AS REWRITTEN}

anteeo, -ī̄ (-īvī), -īre. $\quad a b$ ante (antid l. 2) et ire. $\quad$ scribitur antid- apud PlaVt. (sc. fere in var. $l$. [restituendum vid. Bacch. frg. 23 pro antěít], sed trad. cod. A Trin. 546 antidit, $c f$. ibid. Pseud. 933 anteidibo), ante ire puncto interposito CE 1177, 3, antire sim. trad. PS. SALL. rep. 2, 8, 2 (sed ante- 2, 5, 3). TAC. ann. 3, 69,

5 3. 4, 71, 1. 5, 6, 3. al. (sed ante- e.g. 1, 64, 4. 15, 18, 3) et hic illic in var. l. de for $m$ is : abundat indic. i m p e rf.; exstat pa s s . pers. CIC. Sull. 23 (inf. ut LIV. 6, 34, 7 SEN. dial. 1, 3, 14). TAC. hist. 2, 101, 1, vix etiam l. 97; formae p e rfe c t $i$ ( $c f$. PROB. cath. gramm. IV 34, 14 littera e ante eo posita ... tempus perfectum ivi vel ii facit, ut ... -ivi praeivi vel -ii praeii): -ii sim.: -iit Ov. fast. 6, 117 TAC. ann. 3, 30, 2.

10 al., -ieris FORTVN. gramm. VI 278, 10 (-ire trad.); formae c o n tr a c t a e (cf.l. 4): -istis Liv. 38, 51, 11; -isset StAT. Theb. 6, 485 GELl. 2, 26, 20; -issent TAC. ann. 15, 18, 3 HIL. in Matth. 4, 16; -isse HIL. in Matth. 4, $17 . \quad$ tm e s is occurrit LVCIL. 1160. Ov. fast. 6, 117 (v. l. 144). Pont. 4, 7, 52 Stat. Theb. 6, 485 . de proso d i a : excepto solo AVSON. 15 (336 S.), 16 (vix addas PLAVT. l. 2) syllabae secunda et tertia per synaloephen leguntur; $c f . l .4$ l l e g i t u $r$ in poesi inde a PLAVTO, Ter., TrabeA, Lvcil., LvCR.; in prosa oratione inde a RHET. Her., Cic., CAES., SAll. (adamat TAC.); aetate posteriore multo rarius invenitur quam praeire. [falso trad. anteamus pro antea mos ARNOB. nat. 5, 41.]

i. q. p r a e ir e, praecedere (subi. sunt fere animantes, res e. g. l. 51. 62; is

20 qui sequitur indicatur per acc. vel dat. [utramque struct. agnoscunt DIOM. gramm. I 313, 9 sqq. ARVs. gramm. 35] vel facilius intellegitur, sed prorsus deesse videtur sub IIIB): I praevalente respectu gradus, qual it a t is, qua quis (quid) $p r$ a e s t a $t$, melior vel maioris momenti est; exempla, in quibus quis in cursu sim. alios praecedit itaque superat, ad IIIA traximus (saepe pro syn. sunt superare, vincere. accedit abl. limit. passim [gerund. l. 51], pro quo ponitur acc. resp. l. 97, praepos. in c. abl.l. 52. 56 [vix addas l. 55], struct. verbalis l. 33. 80; abl. mens. occurrit l. 32. 34. al., acc. obi. interni l.35.41.48, cf. adv. longe l.30.58. al., facile l.43.80): $\quad$ A indic a t ur quis (quid) postponatur per: $\quad 1$ acc $: \quad$ a a nimantium (sc. fere hominum; animalium l. 40. 41. 48; addas etiam l. 32. 51. exempla selecta inde

$30 \quad a$ TAC.): PLAVT. Bacch. 1089 solus ego o $\mathrm{m} \mathrm{n}$ is longe -eo stultitia et moribus indoctis (Cist. 205 o. homines supero [atque] -eo cruciabilitatibus animi. CIC. nat. deor. 2, 153 hominis natura quanto o. -ret animantes. SALL. Iug. 6, 1. NeP. Chabr. 4, 1 l. 46. al.; cf. cunctos: SIL. 5, 355 medicus quidam ferrum ... e corpore ... exigere ... -ibat c. CE 1238, 11 [saec. III?]. al.). frg. 23 hic adulescens multo Vlixem -it. Pseud. 35933 te ... dolis atque mendaciis, qui magister mihi es, -bo. TER. Phorm. 247 quantum erum -eo sapientia (explicat EVGRAPH. praeire, SCHOL. Ter. p. 131, 2 praecello). CIC. Sull. 23 nec se aequales tui propter istam causam (sc. quod tu patricius sis) abs te -iri putant (postea: nec patientur se abs te, nisi virtute vincentur, honore superari). ac. 1, 35 Zeno cum Arcesilam -ret a e t a t e (SALl. hist. frg. 1, 75 l. 42; cf. Avson. 15 40 (336 S.), 16 tris cervorum aeripedum ... aetates superat Phoebius oscen, quem novies senior Gangeticus -it ales). BELL. Alex. 38, 4 multum numero -ibat nostrum equitatum. SALL. hist. frg. 1, 75 Philippus aetate et consilio c e te ro s -ibat (TAC. hist. 4, 13, 1 ann. 11, 17, 1. al.). or. Phil. 13 boni malos facile -ibant. PS. SALL. rep. 2, 5, 3 neque 
divitiis aut superbia, sed bona $\mathrm{f}$ a $\mathrm{m}$ a factisque fortibus nobilis ignobilem -ibat (TAC. hist. 3, 38, 2 eum omni dedecore maculosum egregia f. -ibat. $c f . l .66$ ). 2, 8, 2 virtute

45 (NEP. Thras. 1, 3 cum eum nemo -ret his virtutibus, multi nobilitate praecucurrerunt. IVST. 1, 2, 6. cf. l. 84). NeP. Chabr. 4, 1 omnes ... a u c t or i t a t e -ibat (Liv. 35, 25,7 omnes ... prudentia et a. TAC. hist. 3, 65, 1 a. pecuniaque Vespasianum). Ov. Pont. 4, 7, 52 tantum virtus alios tua praeterit omnes, ante citos quantum Pegasus ibat equos. Liv. 6, 30, 3 Manlii genere p 1 e b e i o s, gratia Iulium -ibant (39, 40, 3 omnes 50 patricios p.que). 6, 34, 7. SEN. benef. 3, 36, 1 (in imagine) virtus ... -ire priores cupit. dial. 1, 3, 14. STAT. Theb. 3, 156 Ogygias titulis -ire parentes. 4, 182 doctas -ire canendo Aonidas. TAC. dial. 36, 4 in ipsis honoribus collegas suos -ibat. hist. 2, 76, 3 Nero n o bilit a te natalium Vitellium -ibat ([antea: splendidior origine]. ann. 11, 17, 1. cf. l. 49 nec non TAC. hist. 4, 13, 1 quidam regia stirpe multo[s] ceteros -ibant). ann. 3,

55 1, 4 comitatum Agrippinae longo maerore fessum planctus obvii et recentes in dolore -ibant. al. GELL. 19, 9, 8 sicut in voluptatibus cultus atque victus, ita in cantilenarum quoque mollitiis (multis trad.) -retis quendam (antea: vinceretis). PORPH. Hor. sat. 1, 7, 8 ('praecurreret') longe -ret. al.

b r e r um (sc. personatarum l. 60 sq.; '-ire qualitatem alicuius' pro 'ali-

60 quem -ire qualitate' e. g. l. 65. 77): PLAVT. Cas. 225 munditiis Munditiam -eo ( sim. TRABEA com. 5 Fortunam ipsam -bo fortunis meis). RHET. Her. 3, 6, 11 (de laudationibus) ipsa facta omnium laudatorum eloquentiam -ire. VERG. Aen. 12, 84 equi

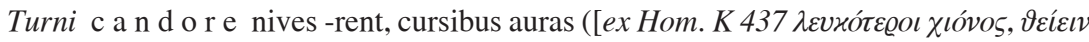

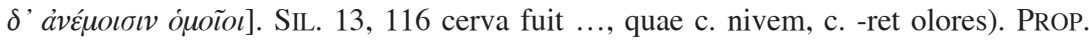

65 1, 6, 19 (amico proconsulem peregre secuturo) tu patrui meritas conare -ire secures fascium (i. patruum potestate sim.) ...; me sine eqs. (sunt qui ad IIIA trahant). 2, 3, 41 fama tabulas pictas -ire vetustas. Ov. met. 13, 366 quanto ... ratem qui temperat -it remigis officium, ... tantum ego te supero. SIL. 2, 348 turmae ... Libycae certant annos -ire labore (vergit ad IIA2). 16, 561 iaculator insignis ventos -ire lacerto ( $c f$.

70 auras $l$. 63). STAT. Theb. 7, 339 Cydoneas -bunt (-ibant var. l.) gaesa sagittas. TAC. ann. 3, 66, 4 aequalis, dein superiores, postremo suasmet ipse spes -ire parat. 4, 40, 5 (Tiberius Seiano) te excessisse ... equestre fastigium longeque -isse patris mei amicitias (i. amicos). al. APVL. met. 4, 2, 4 ille conatus asini currentis fortunae ... scaevitatem -ire non potuit (sc. velocitate sim.). HIL. in Matth. 4, 16 nisi iustitiam Pharisaeorum

75 aequitate -issent. АMM. 28, 4, 31 (hyperbolice) spectatores festinant praecipites, ut velocitate currus ipsos «-ant» certaturos («» anteeaint $M$, anteea in $V$ ). MART. CAP. 9, 908 virginum chorus ... omnes praecedentium suavitatum dulcedines -ibat. EvSTATH. Basil. hex. 8, 7, 16 pernicitatem volatilium ... pedibus -ire (antea: superari; non eadem

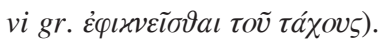

2 d a $t$.:

a a nimantium:

PlaVt. Persa 778 solus ego o $\mathrm{m} \mathrm{n}$ i b u s -eo facile, miserrumus hominum ut vivam (CIC. Brut. 229 consules o. [Diom. gramm. I 313, 10, omnes codd. Cic.] intellegentia -ibant). Cic. Phil. 9, 1 cum ... a e $t$ a t e illis -ret, sapientia omnibus ([illos ... omnes var. l.]. Tusc. 1, 5 his a. -ibat). off. 2, 37 admiratione ... afficiuntur ii qui -ire c e t e r i s virtute putantur (AvG. civ.

8515,9 p. 75,15 gigantes longe c. -ibant, sc. magnitudine corporis [syn. excederent]. $c f$. l. 89). b rer um ('qualitati alicuius' pro 'alicui qualitate' l. 87): Plavt. 
Amph. 649 virtus omnibus rebus -it. CIC. fin. 5, 93 minimam praestantiam animi omnibus bonis corporis -ire. TAC. ann. 5, 3,1 neque Seianus audebat auctoritati parentis -ire. GELL. 1, 1, 3 Pythagoras computavit tanto fuisse Herculem corpore excelsiorem quam alios, quanto Olympicum stadium c e t e $r$ is $\ldots$-ret $(1,22,10$ copia ... et facultate [syn. supra fuit et praestitit superavitque]). FAV. EVL. 23, 4 tres duobus uno -ire numero.

B c e t e r a exempla: PLAVT. Trin. 546 Campans genus multo Surorum (sc. genus vel generi) iam -it patientia (simili ellipsi: Cic. Att. 12, 31, 2 quantum -ire istos hortos, sc. Silii, Drusi [cf. 12, 25, 2 antepono]). Cic. Lael. 69 Scipio quendam, quod is -ibat aetate, tamquam superiorem colebat. CAES. civ. 1, 32, 9 Pompeium, ut operibus -ire (-iri et ante var. $l l$.) studuerit, sic iustitia et aequitate velle superare. LIV. 28, 9, 11 quantum merito -ibat, tantum honore conlegae cesserat. SIL. 9, 437 viri dextra ... pares, sed cetera ductor -ibat Latius, melior pietate fideque. TAC. hist. 3, 31, 1 ut quis

100 ordine -ibat, cedere fortunae. ann. 2, 43, 5 Germanicus c la rit u d in e mater $<$ ni $>$ g e $n$ e r i s -ibat (12, 6, 1 Agrippina). GELl. 2, 26, 20. 20, 5, 8 ego doctrina -ire malim quam copiis et opulentiis (syn. praestare). SoL. 15, 3 quanto quis -it, tanto propensiore nota tinguitur, ut sit indicium humilitatis minus pingi (e Mela 2, 1, 10 maioribus praestant). ARNOB. nat. 4, 37 quoniam plurimum gladiis et potestate valetis

105 ferri, -ire vos etiam veritatis scientia iudicetis. PS. MAR. VICTORIN. gramm. VI 49, 11 pedes quidam aut eiusdem inter se mensurae sunt aut sescuplo -eunt aut duplo. CoD. Theod. 1, 9, 2 is gradu ceteros antecedat, quem stipendia longiora vel labor prolixior fecerit -ire. al.

II praevalente respectu te m por is (accedit abl. mens. l. 129); -eunt qui 110 (quae): A praeveniunt, anticipant (sc. actionibus sim.; huc referam

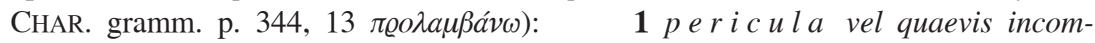
moda: a cum obi. a c c . vel obi. supplendo: TER. Andr. 556 amantium irae amoris integratiost. :: em id te oro ut -eamu', dum tempus datur (explicat EvGRAPH. quid fieri possit providens praecedere temptat). GRATT. 385 sit $<\mathrm{t}>\mathrm{utius}$... rabiem -ire

115 auxiliis et primas vincere causas. VAL. FL. 1, 31 -ire metus iuvenemque exstinguere pergit Aesonium Pelias. SIL. 13, 617 Venus, insidias -ire laborans Iunonis. TAC. ann. 5, 6, 3 liber et mihi ipsi probatus -bo periculum (sc. morte vol un taria ut: 6, 29, 4 damnationem [13, 30, 1 veneno]). 12, 27, 2 auxiliares monitos, ut -rent populatores vel dilapsis improvisi circumfunderentur. al. ARNOB. nat. 5, 3 (syn. anteverteret).

120 b pro obi. est e nunt. in te r ro g., ut vergat in notionem praesentiendi: SIL. 14, 456 quid Boreas, quid vellet crastinus Auster, -ibat gubernator.

2 c e te r a exempla (cf. l. 68): LIV. 38, 51, 11 (Scipio ad Quirites) si vos a e $\mathrm{t}$ a $\mathrm{t}$ e $\mathrm{m}$ meam honoribus vestris -istis, ego vestros honores rebus gerendis praecessi (HIER. epist. 79, 2, 1 inter ... honorum culmina quae a. -ibant). TAC. ann. 4, 71, 1 (in 125 imagine) avebat animus -ire statimque memorare exitus ...; verum has ... poenas in tempore trademus.

B ordine priores (priora) sunt: $\quad$ CIC. fat. 44 si concedunt -ire visa eqs. (antea: viso antecedente). TAC. ann. 3, 69, 3 si -issent delicta, poenae sequerentur. ARNOB. nat. 2, 72 at religiones vestrae multis annis praecedunt nostram; ... quid eas 130 prodest annis quam plurimis -ire? (item cum a bl. me $n$ s .: 4, 8 deos saeculis cuncta 
... -ire). RvFIn. hist. 1, 5, 1 posteaquam ... ea, quae historicam narrationem debuerant

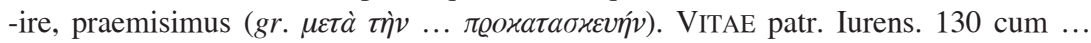
oratu longissimo atque secreto cunctos in oratorium diutissime -ret.

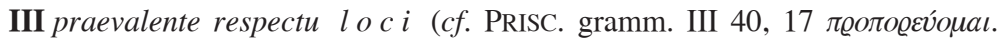

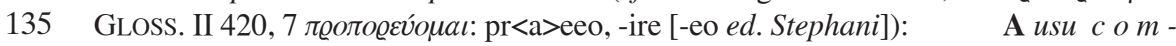
mun $i$, sc. aliquibus s u b s eque n tibus (cf.quae supral.24 adnotavimus); quis (quid) sequatur: 1 intellegitur e contextu: LVCIL. 1160 (in veriloquio) praetorum est ante et praeire (item de $d$ u c i b u s militaribus: SVET. Iul. 57 in agmine nonnumquam equo, saepius pedibus -ibat. cf. l. 167). CIC. off. 2, 25 (inde VAL. MAX.

1409,13 ext. 3) barbarum ... destricto gladio iubebat -ire praemittebatque de stipatoribus suis. LVCR. 4, 139 montes avolsaque saxa montibus -ire et solem succedere praeter cernuntur in nubibus (an ad B? vix ad 2). Hor. epist. 1, 2, 70 quodsi cessas aut strenuus -is, nec tardum opperior nec praecedentibus insto. Ov. met. 11, 65 Orpheus nunc praecedentem Eurydicen sequitur, nunc praevius -it. fast. 6, 117 iuvenis ante ut iit (ante

145 iit [vel ut], ut ante hoc var. ll.), ... nympha resistit (116 si ... ducis, ... sequor). LIV. 1, 59,6 quacumque incedit armata multitudo, ... tumultum facit; rursus ubi -ire primores civitatis vident cives, eqs. 24, 44, 10 cum consul progrederetur lictoresque ... -rent (de iisdem cf. l. 154). FEST. p. 245 antiqui praepetere <dicebant pro -ire> (restit. sec. PAVL. FEST. p. 244). STAT. Theb. 6, 485 aurigam quendam fracto curru deturbat, et isset ante

150 Chromis. TAC. ann. 1, 64, 4 ut dux hostem silvis coerceret, donec saucii quantumque gravioris agminis -rent. SVET. Aug. 64, 3 neque iter fecit, nisi ut «vehiculo»-rent aut circa adequitarent nepotes («»abl. instr., vix dat. intellegas ut ad 2 spectet). HIL. in psalm. 118 heth p. 400, 8 columna ignis nocturno tempore -ibat (sim. p. 400, 11 [syn. provehebatur]). 2 indicatur per dat. (vix huc l. 141. 151): $\quad$ CIC. leg. agr. 2,

15593 duumviris Campanis -ibant $1 \mathrm{i}$ c t o r e s non cum bacillis, sed, ut hic praetoribus urbanis -eunt, cum fascibus bini (rep. 2, 31 sibi, sc. regi). $\quad 3$ indicatur per a c c . (vix huc l. 118): HoR. carm. 1, 35, 17 te, Fortuna, semper -it saeva Necessitas ( $c f$. STAT. Theb. 7, 109 Mars Pavorem quadripedes -ire iubet). Ov. ars 2, 726 (in imagine de coitu) ne cursus -eat illa domina tuos; ad metam properate simul. MANIL. 5, 77

160 (hyperbolice) aurigam exagitare feros equos pronumque -ire volantis. SEN. Ag. 453 delphinus -ire naves laetus et rursus sequi. epist. 90, 31 sapiens c u r s u omnis -bit qua velox est, non qua sapiens (MAXIM. eleg. 1, 27 [in imagine] nunc agili c. cunctos -ire solebam, nunc tragici cantus exsuperare melos [an ad IAla?]). CVRT. 3, 3, $15 \mathrm{c} \mathrm{u} \mathrm{r} \mathrm{r} \mathrm{u} \mathrm{m}$ regis -ibant doryphoroe (CLAVD. 28, 377 [in triumpho] ut Massyla tuos -rent oppida

165 c.). PLIN. nat. 10, 16 in bello signa quaedam singulos ordines -ibant. TAC. hist. 1, 45, 1 ruere cuncti in castra, -ire (ante hire $M$ ) proximos, certare cum praecedentibus. 2, 5, 1 Vespasianus acer militiae -ire agmen (item de d u c i bus militaribus: PLIN. paneg. 10,3 vexilla, ... aquilas magno gradu. AMM. 16, 12, 24 cornu sinistrum [syn. agebat]). 2, 30, 1 milites nolle requiem, non expectare ducem, -ire signa, urguere signiferos. SoL.

170 2, 46 inter aves duces duo sunt, qui regunt cursum: alter agmen -it, alter insequitur (sec. Plin. nat. 10, 126, ubi ducere). LACT. epit. 67, 1 -bit eum Christum claritas ignea et virtus ... angelorum (inst. 7, 19, 5 antecedet). al.

B usu sing u lari de eis qui procedunt, sc. nullis subsequentibus (cf. l. 141): STAT. Theb. 10, 394 quidam exclamat 'cohibete gradum', ... sed miseri 175 pergunt -ire.

Corbeill. 